\title{
The Great European Museum
}

\section{Kenneth Hudson}

Recently, I had to spend a few days in the beautiful French town of Dinard, which is a very fine museum in itself. I hope you noticed that I said 'museum', not 'museum piece', which would have indicated that Dinard is frozen in the past, with no useful part to play in today's world. Dinard is not like that at all. It is a prosperous, attractive, well-maintained town, which has shown great skill in adapting itself to changing social habits and in making full use of its splendid location, on the Atlantic coast, facing St Malo across the estuary of the Rance. King Edward VII loved it and the modern boat-people love it, and in both cases one can understand why.

Why do I call it 'a fine museum'? Partly because it preserves its past so admirably, partly because it is such a tempting and satisfactory place for sorting out and identifying the different layers in its manmade past, and for understanding the contributions which each decade has made to the appearance and functioning of its streets and buildings and gardens. Understanding is not a passive process. It implies curiosity, personal effort, knowledge and a willingness to break away from conventional thinking. Suppose, for instance, that one is staying in a hotel of the modest 50-bed, two-star type, such as Printania, which had the privilege of accommodating me. A great range of interlocking questions came to my mind throughout my stay there. How much of the hotel furniture that surrounded me was there 50 or 100 years ago? How, if at all, had the atmosphere changed? Would everything have been a good deal more formal in the Twenties or Thirties? Most of the people who were there with me in August 1993 were distinctly on the elderly side. Would it have been the same in August 1933 or August 1903? Has the national mix stayed the same, with a lot of English, German and Dutch and rather fewer French? How do the food and drink today compare with what was available in one's father's or grandfather's time? Today all the rooms have bathrooms. How many bathrooms were there in the hotel in Edwardian days? One on each floor, perhaps. When was electricity first installed? How superior would the accommodation and service have been at the four-star George V Hotel along the road?

Every type of building and every street stimulates its own complex of questions, but one has first to assume that, to the enthusiast, all questions are equally interesting and equally relevant. It is pure snobbery to think that Dinard's ornate 
52 casino is interesting and the little houses round the corner are not. The Casino, with its successive generations of rich and foolish people with a passion for gambling who have formed the clientèle of the Casino for nearly a century, is no better evidence of life and work of the town than the houses and apartments where the Casino staff have lived generation by generation. The Great Dinard Museum necessarily includes them both.

\section{INTERESTING AND OFFICIALLY INTERESTING}

But, in order to understand what one is looking at, two things are essential. The first is an adequate supply of information, of clues, and the second and much more difficult to achieve is an unfettered mind. Let me explain what I mean by 'an unfettered mind'.

"Man is born free, but everywhere he is in chains", wrote Rousseau, and it is as true now as it was in 1762. One is tempted to paraphrase Rousseau by saying that small children are interested in everything, but adults in only a very small range of subjects. Children's natural wide-ranging curiosity is gradually stifled by education to such an extent that those who receive the longest and most thoroughgoing education often finish up by being interested in the fewest things.

This is particularly caused by extreme specialisation, but even more by a set of social conventions which progressively condition people to believe that one should concern oneself only with those things that are, so to speak, officially interesting and leave the rest to eccentrics and misfits. An education which encourages this is, of course, a bogus education, but its effects are none the less real, powerful and widespread. How can museums improve the situation? To a certain extent museums are in the same position as television or newspapers. If something, a fact or an opinion, has appeared on television or in a newspaper, it is officially interesting and therefore respectable. It has been pulled from the darkness into the light. Similarly, if a museum organises an exhibition, the subject of the exhibition has been graded up and made worthy of attention, achieved a breakthrough. There are, of course, complicating factors. No modern society is homogeneous and one is likely to enlarge the range of one's sympathies and interests only if one's particular peer-group is not hostile to the process. Few people possess either the courage or the stamina to depart widely from the code of what one feels to be one's peer-group, which is the main reason why the habit of museum-going is so limited. It takes a very powerful incentive to persuade people to cross the peer-group line. In general, the majority of Europeans are not museum-goers at the present time, and I doubt if any considerable change is likely to take place in the future, at any rate among adults. Children are another matter. School groups who attend muse-ums do so as conscripts. They may enjoy the museum more than school, but that is a different story. The choice as to whether they go to the museum or not is not theirs. It is made for them and I should be surprised if conscript-visiting among children has any more effect on later adult behaviour than compulsory churchgoing does.

A common feature of both churchgoing and museum-visiting is that it almost invariably involves crossing a threshold, 
entering a building, leaving the outside world behind. With the Great Dinard Museum, the Great Moscow Museum, or the Great Swiss Museum, however, the circumstances are quite different. One enters the Great Museum, whatever its boundaries may be, simply by being born. One is surrounded by its collections and displays all the time and one escapes from them only by moving somewhere else or by staying inside one's own house all the time. Membership of some part of the Great Museum is virtually compulsory and free, but this does not mean that everyone who moves around in the Great Museum is in a position to take an intelligent, informed interest in what it has to offer. Most of its customers are vaguely aware of what they are looking at, to fit the bits and pieces into meaningful patterns.

Several city museums in Europe museums which set out to tell the story of a city in all its aspects - have a programme of guided city walks around selected areas of the city. These aim at bringing the city alive by means of on-the-spot interpretation. The museums of Barcelona and Stockholm do this particularly well, either by following a theme or by concentrating on one particular area at a time. During these tours, what might be called the normal or stereotype museum is doing its best to make a piece of the Great Museum interesting and to give those members of the public who take part sharper and more widely-ranging eyes than they had before. Often, perhaps usually, curative treatment is necessary for a lifetime of bad habits, chief among which is the belief that one should give one's attention only to famous and therefore untypical buildings.

The Great Museums are not necessarily urban. For many centuries man has been actively engaged in putting his thumbprint on the rural areas as well and it is evident that the man in the street is just as poorly equipped to make sense of the history of the countryside as of that of the towns. A little ruthless testing during car drives or train journeys through, say, England, Germany or France is likely to reveal that sadly few of one's fellow travellers have much, if any, idea of what crops are growing in the fields or what jobs the tractor-drivers are doing. Few of them, also, can name common trees or distinguish between one breed of cow or another. They are visually illiterate. What they are looking at means almost nothing to them.

And if they cannot understand the countryside today, what point is there in trying to explain to them the changes to which each field and village have been subjected during the past 100 years or more, in what ways the cropping patterns and cultivation methods are different, why fewer people are required to work the land now than in previous generations, the ways in which man's need to earn a living has transformed the landscape generation after generation.

\section{WHAT MAKES EUROPE SPECIAL?}

It is interesting to try to identify the factors which have combined to give Europe its special charcter, distinguishing it from all other continents. This amounts to asking why the Great European Museum is different from, say, the Great American Museum or the Great Chinese Museum. One can and should break these big regions down further. The Great European Museum is made up of the Great Dutch 
KENNETH HUDSON

54 Museum, The Great Spanish Museum, The Great Bulgarian Museum and so on, just as the Great Iowa Museum and the Great Texas Museum are among the ingredients in the Great American Museum pudding. The English person who is not aware of what makes England peculiar is not well placed to understand the European mix of qualities.

One can argue for ever about the essential features of Europe, those which give the continent a flavour of its own. Here are some of the ones which seem to me to be the most important. They can be added to and refined without too much difficulty. First, Europe is, on the whole, a green continent, blessed with a substantial rainfall. Its surface area contains little in the way of deserts and droughts lasting for several years are rare. Second, and arising partly from its absence of extreme heat, Europe is an energetic continent, one where work can usually be carried on without undue exhaustion all day and throughout the year. Without energy, technical and scientific inventiveness are unlikely to occur, and Europe has been a world-source of technical innovation for a long time. It has produced, among other new ideas, the steam-engine, railways, the powerloom and the technique of smelting iron with coke, developments which combined to make the industrial revolution possible. For better or worse, Europe was the cradle of the Industrial Revolution.

Other important and unifying items in the European mix have been Romanisation and the Latin language, Christian thinking and practice, and an interlocking framework of royal and aristocratic families. The Jewish contribution to European culture and economic growth has been very great. It has, unfortunately, been associated with widespread persecution of the Jews, on a scale not found elsewhere in the world. Europe has also been marked by great suffering caused by wars, nationalism and power-drunk conquerors who had dreams of becoming masters of Europe. And, as a result of its energy and its technical superiority, Europe gradually acquired vast overseas possessions. From Roman times onwards, Europe created colonial empires to an extent not matched by any other continent.

It was in Europe, too, that the first museums were born. Museums are very much a European invention, established at first to allow royalty and aristocrats to show off the collections which their power and wealth had allowed them to assemble and then as part of the process of public education. All the aspects Europeanness which I have mentioned are illustrated by museums. We have museums which show the achievement of Rome and of Christianity, Jewish museums, technical and industrial museums, natural history museums, agricultural museums, military and naval museums, empire museums, Napoleonic museums and transport museums. A high proportion of Europe's palaces and grand country houses have been turned into museums and the art collections of kings, dukes and princes have become public property, accessible to the general public.

What has taken place in every European country over the past two hundred years has been essentially a process of putting Europe's history into the safety of what are in effect cultural banks or fortresses, where precious relics can be both presented and conserved, in an attempt to pre- 
vent or at least delay the destructive influence of time. The comparison with a bank or fortress is strengthened by the presence in the museum of alarm systems, warders (museum policemen) and fire protection devices. One could also use the word 'island'. Museums are carefully defended islands in a turbulent sea infested with sharks and pirates.

The first serious attempt to break down the fortress mentality was made by the early ecomuseums, particularly Le Creusot, which pioneered in the 1960s the concept of a district as a museum. The ecomuseum was not required to own its territory, but to hold cultural power over it. "At Le Creusot", said Marcel Evrard, its first director, "every tree, every cow, every building is an exhibit in the museum. I myself is an exhibit in my own museum." The museum which really mattered at Le Creusot was therefore not the interpretation centre in the 18th century chateau but the area of countryside around it and everything it contained. This might be termed the Great Le Creusot Museum, with its houses, farms, factories, workshops and people with family histories and memories. The primary objective of $\mathrm{Mr}$ Evrard and his colleages was to make the past and present of this area meaningful and interesting to the people who lived and worked in it, to help them to discover the clues that would make better sense of it all. And that, I am suggesting, is what most museums should be doing. What is important is not what is in the museum, but the power of its collections and displays to increase and enrich people's understanding of the world outside and around them, of the Grest Museum. The museum which regards itself as a self-contained entity has failed.
From a museum point of view, I see every town, village, landscape, country and even continent as a Great Museum in which everyone can discover their own roots and see how they fit into the chain of human activities which stretches back over the centuries. Scattered over the Great Museum are the institutions which we have chosen to call museums, demanding that their cultural importance shall be recognised and insisting that they shall be given an ever-increasing supply of public money in order to do what they conceive to be their job, that job being, to use the professional phrase, 'acquisition, conservation and display'. This, one could fairly say, has been the motto of the miser throughout the ages and it is, in my view, a totally inadequate and discredited recipe, both for success and for public esteem. The real reason for a museum's existence is to make life more interesting and more rewarding for its customers. One could say exactly the same about a school or a church, neither of which exists for its own sake.

\section{THE MUSEUM AS AN ATTITUDE-CHANGER}

A museum, like a school or a church, justifies its existence much more for its success in changing people's attitudes than by adding to their stock of information. One or two examples will illustrate what I mean.

In Greece, Niki Goulandris was appalled by the fact that her fellow-countrymen appeared to take practically no interest in wild creatures or in the natural environment as a whole. As in most other parts of the Middle East, the Greek attitude towards animals is at best indifferent and at 
KENNETH HUDSON

56 worst abominable. There are, for example, no guide dogs for the blind in Greece, because people refuse to allow them on to buses and trains. 20 years ago there was no natural history museum in the whole of Greece, so Mrs Goulandris and her husband decided to establish one, using their own money, at Kifissia, on the outskirts of Athens. It was large and designed to international standards and, once it was open, Greece had, for the first time, a National Museum of Natural History. Later, she set up a branch museum on Corfu and a forestry reserve in the north of the country. Her aim was to interest children in natural history, and after a slow start, she has succeeded remarkably well. A generation of schoolchildren has now grown up understanding why and how Greece should protect its natural environment and take pleasure in observing and caring for wild creatures. Greek children are now keeping pets, a revolution in itself. The main point of creating the museum was to change children's attitudes and this is gradually being accomplished, and a new dimension is being added to the Great Greek Museum. The primary target was children. Greek adults were felt to be settled in their ways, too deeply conditioned - corrupted according to modern standards - by the habits and beliefs of their ancestors.

Niki Goulandris has always regarded her museum as a working tool, not as an institutional end in itself and this, too, has been the view of another of Europe's great museum personalities, Aleid RensenOosting, the creator and director of the Noorder Dierenpark at Emmen, in the north of Holland. Her aim for more than 20 years has been to establish a mus- eum/zoo which would illustrate the story of life on earth, and equip its visitors to take an intelligent interest in wild creatures and to understand how man and animals can inhabit the world more satisfactorily together. The Noorder Dieren-park is where they come - nearly two million of them each year - in order to develop a modern, constructive philosophy and, on subsequent visits, to recharge their batteries. Aleid Rensen-Oosting has broken down the barriers between academic subjects and constructed exhibitions which approach from many different angles the problems and opportunities involved in building bridges between man and the natural world.

Niki Goulandris and Aleid RensenOosting have very similar motives and philosophies. They see themselves as missionaries who want to send people away from their museums better than they found them, believing that the Great Greek Museum and the Great Dutch Museum will be better places to live in as a result of their efforts. In a completely different field, the Building of Bath Museum is trying to do something equally important. Bath likes to think of itself as the finest of all Europe's 18th-century cities and there is quite a lot to be said in support of this claim. But the international reputation and tourist success of the city owes much to snobbery and to an exaggerated respect for architecture as such, especially Georgian architecture. The Building of Bath Museum represents an attempt to put the city's architecture and architects in their place. It emphasises that the carpenters, joiners, masons, tilers and plasterers were the real builders of Bath and that without their skills the architects, who have received all the cre- 
dit, would not have been able to make their reputations. The new museum therefore shows its visitors the tools, techniques and materials used by craftsmen who, in the real sense, built Bath. After this introduction and re-emphasis, it organises guided tours around the city in order to demonstrate the practical aspects of Bath's 18 th and early 19 th-century buildings and to show how the architects and the building tradesmen depended on one another. The tours, like the Museum itself, aim at arousing curiosity and at providing people with a wider, deeper and more ciritical understanding of the buildings which they have often crossed the Atlantic to see.

There are many different ways of regarding towns, history and the countryside and one would certainly not want or expect everyone to be interested in the same things. What is important is, first, to recreate childhood curiosity and, second, to satisfy it. An excellent illustration of this process is to be found in and around the small town of Göppingen, near Stuttgart. Until the Nazis got to work, Göppingen had a substantial Jewish community, mostly living in an area on the southern outskirts of the town. There are no Jews left in Göppingen, but their houses, shops and workshops are still there, together with a former Jewish inn and a well-preserved Jewish cemetery. Recently a Jewish museum has been set up, in a superannuated Protestant church. The slight shock of finding a Jewish museum in a 16th-century Christian church is very useful, because the curiosity and interest of visitors to the museum are aroused from the time they open the door.

Inside the church, on both the ground floor and in the gallery, there is an excel- lently conceived exhibition about the local Jewish community. It is not built around generalisations about the persecution of Jews by the Nazis, but on the story of what actually happened to individual Jews and Jewish families in Göppingen, showing at the same time the place where each Jewish family had established themselves within the community. This is a museum about real Jews.

Briefed in this way, one can take a walk around the town, looking at the houses where the Jews used to live and thinking about the people, who, in one way or another, gained possession of the property of the people who met their end in the concentration camps, about the present inhabitants of this part of Göppingen and about the days when the local Jews were regarded and treated as normal citizens. One can also walk around the beautifullymaintained Jewish cemetery, looking at dates and the names of families, noting which people were obviously grand and which more humble and observing when the traditional Jewish custom of never burying males and females in the same grave began to be abandoned.

It would be difficult to find a better example of how within-a-building museum can help to develop a better understanding of the Great Museum. Left to their own devices, how many visitors to Göppingen or, for that matter, how many people who live there would realise the historical significance of this street in the town or know why the inn was called the King David? How many of them could see them just as ordinary houses after learning about the fate of their inhabitants during a visit in the museum?

Information is most valuable, of course, 
58 when it is available at the place to which it relates. The best situation, I suppose, would be one in which each street had its history panel. I once stayed at a hotel in the Pyrenees, run by an elderly Englishwoman, in which each room contained a list, fixed to the wall by the light switch, of the international celebrities who had slept in the bed which I myself was later to occupy. The Queen of the Belgians, I remember, was one of them. To lie there in the knowledge that she had looked at the same ceiling that I was looking at was a curious experience. But in order to make such a powerful impression on the hotel guests, the list of one's predecessors had to be actually there in the room. Old visitors' books, kept downstairs at the reception desk, would not have been at all the same thing.

We are talking about ghosts and the evocation of ghosts is an extremely important element in the understanding of history. The art of interpreting the Great Museum consists to a large extent of helping one's contemporaries to call up ghosts from the past. The ghosts are necessary in order to bring history alive. In Göppingen, the true function of the Jewish Museum is to give today's people the wish and the power to feel the presence of yesterday's persecuted and murdered Jews when they walked through the old Jewish quarter of the town. In the hotel in the Pyrenees, the list of names in the bedroom made it possible to see the Queen of the Belgians doing her hair at the dressing table by the window.

Three years ago, one of my favourite museums, the Women's Museum in Aarhus, put on a marvellous exhibition which bridged the museum and the city in a most interesting way. There was a large,

building-by-building model of the principal shopping street in Aarhus. The history of every building had been carefully researched in order to show, during the 19th and 20th centuries, who had owned and run each shop. From this information, it was then possible to discover how many of these shops and what kind of shops had ever been run by women. The next stage was to construct a mock-up of a number of the interiors of these shops, using wherever possible original material from the shop. The effect was extraordinary. Visitors to the museum were unable to look at the street in the same way again. They had, in effect, been given new eyes and a new attitude to history. This, of course, is what the museum feels its mission to be, to encourage and help people to see Danish history from a woman's point of view, to interpret the environment in a different way.

\section{THE MUSEUM AS A MARRIAGE OF HEAD AND HEART}

Providing new eyes with which to see and understand familiar things is, one would have thought, the prime duty of every museum, as of every educational institution, but it is, alas, a duty that by no means all museums appear to accept and welcome. There are, I believe, two things which make so many museums sterile and, in a real sense, dead. The first is that museums are thought of primarily as intellectual places, where the primary appeal should be to the head not the heart. The second is a corollary and a consequence of the first. Museums are staffed by too many scholars and too few poets. Scholars as we know, are people who mistrust the emotions, pride themselves on objectivity and 
whose education and training cause them to know more and more about less and less. Poets, on the other hand, are essentially irreverent, uncontrollable people, who instinctively sense and try to put into words the relationship between superficially incongruous ideas, objects and events. They have retained and cultivated the child's ability to be curious about everything and interested in everything. They do not see life in terms of facts and they tend to be impatient with those who do and are often contemptuous of them. The best museums, in the sense of the most effective museums, are those which contrive, either by accident or as a result of deliberate policy, to employ a fruitful mixture of the two types of person. But this is rare. By tradition and as a result of snobbery and pressure from professional associations, the scholarly temperament and scholarly habits have come to dominate the museum scene. I am convinced that this has to change, although I would admit that the situation is better in some countries than in others.

What is gradually bringing about a change is, firstly, an increasing shortage of money - scholars are expensive people to employ - and, secondly, the need to increase the size of the museum-going public. What I have called the poetic approach is much more likely to achieve this than the scholarly approach, precisely because a great many more people in any country are governed by their feelings than by their intellect. One could express this in another way by saying that in order to transmit facts and ideas it is necessary first to build an emotional bridge across which they can cross. Nobody ever learnt anything from a teacher they disliked.
The Great Museum is inescapably a museum with a very large public. That public is certainly not homogeneous and to satisfy it and get it to appreciate the museum demands very special skills and a rethinking of the rôle of the museum-ina-building. What are nowadays termed, not always accurately, community museums mark a move in the right direction, but, in my experience, they usually have too limited a view of their field of action.

The real problem, I believe, lies with fine art museums and museums of ethnography, both of which overemphasise their value as institutions and react very strongly against any suggestion that the concept of the Great Museum has anything to offer them. They can see possible links between natural history museums, museums of industry and technology and museums of the applied arts on the one hand and the Great Museum on the other, but they seem, to themselves, to inhabit a world apart. I believe this view to be unnecessarily conservative and pessimistic. The artist's raw material is the world of the Great Museum. It cannot be anywhere else, unless he is working solely in partnership with God. The art museum's business is to show how the artist has distilled his experience of the Great Museum and it can succeed in this only by making constant forays into the Great Museum outside. It is quite possible that the days of the traditional kind of art museum, the museum that earns its living by hanging pictures on walls, are numbered. One is tempted to say, 'and a good thing too'. The modern, worthwhile function of an art museum may consist much less of accumulating closely guarded collections and much more of broadening the taste of 
60 the inhabitants of the Great Museum, in encouraging and helping them to put pictures into their homes and in monitoring the results, in going to the people, in fact, rather than in expecting the people to come to them and to revere their judgement. The temple approach is long outdated.

Similarly, any ethnographical museum in Europe which deliberately follows a come-and-see-our-exotic-wonders policy is committing suicide, quite unnecessarily. Whatever the situation may have been a hundred years ago, there is no country in Europe today which does not contain a variety of non-Europeans among its population. These people, their homes, their occupations, their habits, their physical characteristics, their ways of amusing themselves, their religious beliefs and practices are just as interesting and just as worthy of study and display by museums as the characteristics and customs of yesterday's black, brown and yellow people in their original habitats, which still form the staple diet of most of Europe's ethnographical museums and museum de-partments. For them, as for the art muse-ums, their future success must depend on their willingness and ability to push their fingers into the ethnic communities aro-und them in their own countries and to act as interpreters and mediators with these communities. The waves of both white and non-white immigrants that Europe has somehow managed to accommodate, if not absorb, during the present century constitute an important part of the Great European Museum.

Finally, I should like to offer you a depressing story, told in order to illustrate that there are some Europeans who need a little education in the matter of the Great European Museum. Ten years ago, when the Soviet Union, which we all miss so much, still existed, I happened to be attending a conference in Helsinki. During a break in the proceedings, I was taking a walk around the city in the company of a lady who was the director of what I had better call a large art museum in Moscow. We had reached the square in front of the old Parliament building, where there are statues of a couple of Russian Czars. 'Ah', I said to the Russian lady, 'we are surrounded by the ghosts of the old Russian province of Finland. I can feel Russians here and I am sure you can too.' - 'I don't understand what you mean', she said, 'there are no Russians here!' In the evening we were invited to dinner on the island of Suomenlinna, where there was a fortress and a rather unpleasant prison in Czarist times. 'No Russian ghosts here either?' I said to her, as we stepped ashore from the boat. I got much the same reply as before - 'I don't believe in ghosts', she said, 'not even Russian ghosts.'

The main purpose of the Great European Museum is to help people to raise Europe's ghosts from the dead, to believe in them and to make friends with them.

Kenneth Hudson, välkänd och kontroversiell forffattare, föreläsare och debattör med en närmast encyklopedisk kunskap om världens museer. Sedan 1977 leder han arbetet $i$ den kommitté som delar ut det àrliga europeiska museipriset (EMYA).

Adr: EMYA, PO Box 913, Bristol BS99 5ST,

England. FAX +44272732437. 